\title{
Business Model Adaptation and the Success of New Ventures
}

\section{Bernardo Balboni', Guido Bortoluzzi}

\begin{abstract}
In this study, we explore the connections between business model adaptation and the success of new ventures. We do so by analysing in depth the business model evolution of three new Italian ventures throughout their first years of life. We try to understand if and how the evolution of these firms' business models is connected to their success. Our analysis reveals that adapting their business models was crucial to enabling these firms to survive in extremely dynamic environments. However, it did not fully act as a catalyst for their processes of growth and did not increase their profitability. Keywords: business model adaptation, business model, new ventures, survival, growth.
\end{abstract}

\section{INTRODUCTION}

Many policy makers consider new ventures to be the litmus test for the level of innovativeness and vitality of an economic system and thus give such companies abundant financial support. However, the available empirical evidence shows that a non-negligible amount of new ventures are short lived, do not generate adequate long-term economic returns and do not show substantial growth (Brusoni, Cefis, and Orsenigo, 2006). The managerial literature has identified several drivers of the success of new ventures. Success is defined in the literature as (1) firm survival through the so-called Death Valley; (2) firm growth in revenue and size; and (3) firm profitability (Garnsey, 1998). The three main drivers of success identified in the economic and managerial literature are entrepreneurial factors (the characteristics, attitudes and behaviours of funders), strategic factors (the effectiveness of firms' strategic decisions and the strategic capabilities of firms) and contextual factors (market dynamics, location-specific advantages).

\footnotetext{
1 Bernardo Balboni, PhD, DEAMS Bruno de Finetti University of Trieste, Piazzale Europa, 1 I-34127 Trieste, Italy, tel.: +39040 5587049, e-mail: bernardo.balboni@dreams.units.it.

2 Guido Bortoluzzi, PhD, DEAMS Bruno de Finetti University of Trieste, Piazzale Europa, 1 I-34127 Trieste, Italy, tel.: +39040 5587049, e-mail: guido.bortoluzzi@dreams.units.it.
} 
Some authors claim that, given the increasing complexity of the technological and market environment, firms of every size, age and industry that aim to keep succeeding in their businesses should become more agile in adapting the whole business model of the firm to external contingencies (Chesbrough, 2010; Demil and Lecoq, 2010). The purpose of this study is to explore the connections between business model adaptation (BMA) in new ventures and their success. To do so, we analyse in depth the evolution of the business models of three new ventures throughout their first years of life and try to understand if and how the evolution of their business models is connected to their success. Our analysis reveals that, in all the cases analysed, adapting the business model was crucial to enable these firms to survive in extremely dynamic environments. However, we cannot fully claim that the innovation of the business model acts as a catalyst of their growth process or made them highly profitable. Thus, contrary to the well-established idea that initial business model of innovative start-ups reflects their market potential, our findings emphasise the importance of BMA as a capability which enables new venture survival. Our evidence cannot support that, by adapting the business model, new ventures can accelerate their growth or become highly profitable.

\section{Background}

What increases new ventures' chances of success? This question motivates a considerable amount of empirical research on the conditions that favour the survival and growth of new firms (Delmar, Davidsson and Gartner, 2003; Gilbert, McDougall and Audretsch, 2006). Emphasis is placed on many determinants, including the profile of the founding entrepreneur(s), the characteristics of the business environment and the type of strategies implemented (Song, Podoynitsyna, Van Der Bij and Halman, 2008). Without intending to be exhaustive, we identify three main schools of thought contributing significantly to a better understanding of this topic: (1) entrepreneurial factors; (2) contextual factors; and (3) strategic factors.

Entrepreneurial factors include the personal attributes, mental attitudes and individual skills of the founding entrepreneur(s) (Carland, Hoy and Carland, 1988; Terpstra andOlson, 1993; Bhidé, 2000). The founders' personal characteristics are important in driving the growth of new ventures for several reasons (Amorós, Bosma and Kelley, 2014). First, the individual traits of the founders can shape the innovative culture and strategic behaviour of the firm, leading the new venture along highly challenging but also highly rewarding strategic paths (Mullins, 1996; Baum, Locke and Smith, 2001). Second, founders' education and prior industry experience can provide new 
ventures with a set of knowledge-based assets (e.g. market knowledge, knowledge of competitive dynamics, suppliers and distributors) that can significantly speed firm growth (Birley, 1985; Duchesneau and Gartner, 1990; Hansen, 1995; Sapienza and Grimm, 1997; Stuart and Abetti, 1986; Watson, Steward and Barnir, 2003). Third, external investors often assess the potential of a new venture by considering the founders' individual attributes and are more inclined to support ventures that can guarantee more robust foundations in this regard (Colombo and Grilli, 2005). The same trends hold true for the founding team, which is the topic of analysis in several studies (Eisenhardt and Schoonhoven, 1990; Feeser and Willard, 1990; Zucker, Darby and Brewer, 1998).

Three perspectives are widely adopted in the analysis of contextual factors. First, an emphasis on industry structure and market dynamics dominates in strategic studies as the firm's moves are typically assumed to be triggered by the opportunities (and threats) emerging from the market and to be favoured (or constrained) by the structural characteristics of the industry to which a firm belongs (Davidsson, 1989a, 1989b; Stevenson and Jarillo, 1990). Thus, in these studies, it is assumed that certain markets and industries offer more favourable conditions than others for the success of a new venture (Audretsch, 1995; Vivarelli and Audretsch, 1998). The second perspective focuses on the role of institutional factors (e.g. regulations, culture, norms, infrastructure) in supporting or undermining success. Representative studies from this perspective include the work of Fritsch (1997) and Djankov, McLiesh and Ramalho (2006), who observe that firms generally grow more and faster in countries (or regions) characterised by efficient markets and effective financial and labour regulations. A third perspective considers the specific location of new firms and the characteristics of the local environment. This perspective is highly popular among regional economists, geographers and industrial economists and is adopted in an impressive amount of studies on related concepts, such as industrial clusters (Porter, 1998), industrial districts (Becattini, 1990) and regional innovation systems (Doloreux, 2003).

Local firms benefit from these contextual forces, making location itself a key determinant of firms' performance in survival, growth and profitability. Under certain conditions, a magnet effect is exerted (new suppliers, clients, firms and talents are drawn to the area) which reinforces itself over time (Thakor and Lavack, 2003). Silicon Valley in California is among the representative cases. In the same vein, Glaeser Kallal, Scheinkman and Shleifer (1992) claim that proximity and location play an important role in enabling the diffusion of knowledge-especially tacit knowledge-across firms in a spatially bounded region (Audretsch and Feldman, 1996; Jaffe, 1989; Jaffe, Trajtenberg and Henderson, 1993). Strong inter-firm networks 
which enable knowledge spill-over offer high-tech firms a higher chance of success (Raz and Gloor, 2007) by providing them with access to resources not otherwise available (Witt, 2004). Finally, other scholars emphasise the role played by firms' market strategies and strategic capabilities to explain the growth variation among new ventures (Almus and Nerlinger, 1999; Bloodgood, Sapienza and Almeida, 1996; Li, 2001; Marino and De Noble, 1997; Siegel, Siegel and Macmillan, 1993; Smallbone, Leigh and North, 1995; Zahra and Bogner, 2000).

In an attempt to define the characteristics of market strategies that distinguish high- and low-growth companies, Siegel et al. (1993) find that small, young small companies suffer from resources starvation and so perform better as they focus all their efforts on achieving well-defined goals. Kaplan, Sensoy and Stromberg (2009) present an interesting study. The authors analyse a sample of successful venture-capital-financed companies and examine how firm characteristics evolve from the early business plan to the initial public offering (IPO). Kaplan et al. (2009) conclude that external investors should place more weight on start-ups' business strategy (the horse, in the metaphor used by the authors) than on their management team (the jockey) as having good strategies seems to pay off much more than having good people to carry them out. The Stanford Project on Emerging Companies supports a similar view and suggests that a good business idea and non-human capital assets are relatively more important to the success of a start-up firm than the characteristics of the management team (Baron and Hannan, 2002; Baron, Hannan and Burton, 1999; Beckman and Burton, 2008).

Further studies have attempted to combine the strategic view of the firm with other theoretical perspectives, such as entrepreneurial theory and firm organisational theory, to achieve a more comprehensive explanation of the success of new ventures (e.g. Baum et al., 2001; Chrisman, Bauerschmidt and Hofer, 1998; Sandberg and Hofer, 1987). Much of this literature does not take a completely strategic perspective but, instead, supports a contingency approach in which it is assumed that success is mostly attributable to the fit between internal factors (e.g. the firm's organisational structure and strategies) and characteristics of the external environment (Eisenhardt and Schoonhoven, 1990; Feeser and Willard, 1990).

Regarding strategic capabilities, much of the research on new ventures has focused on the right set of firm-level resources (physical, human and organisational) needed by new ventures to face situations of high market and technological instability (i.e. Teece, Pisano and Shuen, 1997; Eisenhardt and Martin, 2000). In this research stream, the success of new ventures has been attributed mostly to firms' ability to develop a proper internal base 
of resources and competences and to access external resources through networking (Lee, Lee and Pennings, 2001; Heirman and Clarysse, 2004; McDougall, Covin, Robinson and Herron, 1994; Zahra and Bogner, 2002; Zahra, Matherne and Carleton, 2003). The research by Lee et al. (2001) follows this direction and shows that internal capabilities are important predictors of a start-up's growth potential, while among external networks, linkages to venture capital companies are significantly. However, research on startups has neglected the dynamic capability view of the firm (Amit and Zott, 2001; Mezger, 2014). According to Eisenhardt and Martin (2000), dynamic capabilities are 'the organisational and strategic routines by which firms achieve new resource configurations as markets emerge, collide, split, evolve and die' (p. 1107). Teece (2007) describes these routines as meta-capabilities that allow firms to sense market opportunities (and threats), rapidly seize such opportunities and reconfigure their internal bundle of resources and competences in a coherent way. By sharpening dynamic capabilities, new ventures can easily recognise and rapidly exploit profitable market opportunities and avoid remaining stuck with unprofitable business ideas. Additionally, new ventures that rapidly reconfigure their assets are expected to create a more favourable alignment between external (opportunities and threats) and internal (resources and competences) environmental conditions, increasing their ability to grow faster than other firms.

\section{Business model adaptation}

Some recent works shift attention to the concept of the business model, which can provide a coherent framework for explaining how new business ideas are converted into economic value (e.g. Chesbrough and Rosenbloom, 2002; Onetti, Zucchella, Jones and McDougall-Covin, 2012). Despite the lack of a consensus definition of a business model, we can state that the concept generally refers to a set of decisions that relate to a firm's market strategy, organisational structure and the activities it performs both inside and within the business environment through a network of transactions. This concept builds on the literature on business strategy, organisation design, transaction theory and business networks.

In seminal work on business models, Amit and Zott (2001) observe that the business model concept is close to but does not fully coincide with the strategy approach. Indeed, firms compete through their business models, but while the strategy approach emphasises the competitive dimension (value capture), the business model heavily stresses cooperation, partnerships, joint value creation and customer value proposition. Amit and Zott (2001) identify four dimensions of the business model that can influence the value 
creation (and, thus, the growth performance) of a new venture: (1) the business model's degree of novelty; (2) customers' and partners' degree of lock-in to a specific business model; (3) the available complementarities (the possibility of offering a bundle of different products or services through the same business model); and (d) the level of transactional efficiency. This business model concept encompasses and goes beyond strategy formulation (Zott and Amit, 2007, 2008). Casadesus-Masanell and Ricart (2010) observe that the business model reflects a realised strategy and pertains more to strategy execution than to strategy formulation.

Pisano (2006, 2010) and Braguinsky, Honjo, Nagaoka and Nakamura (2010) address the challenge of designing viable business models for scienceand research-based new ventures. Science-based businesses confront three fundamental challenges: 1 ) the need to encourage and reward profound risk taking over long time horizons (the risk management problem); 2) the need to integrate knowledge across highly diverse disciplinary bodies (the integration problem); and 3) the need to accumulate learning (the learning problem). Although each of these challenges-risk, integration, and learning-are present to varying degrees in most business settings, they appear in far greater force and often simultaneously in science-based businesses (Pisano, 2010). Thus, science appears to be a specific environment in which business organisations must develop different and specific models to perform their activities profitably. In other words, we can expect that viable science-based businesses need to design and, over time, adapt business models that are not merely replicas of those prevalent in traditional business settings.

These new business models might also show radical differences at the entrepreneurial level. Indeed, Braguinsky et al. (2010) challenge the conventional view of science-based businesses, which focuses on the inseparability of the roles of the inventor and the Schumpeterian entrepreneur who implements the business in practice. Similar dynamics are observed in the cases of new high-tech ventures. Onetti et al. (2012) emphasise that, today, such firms are forced to develop a broad strategic vision and global competitive strategies and capabilities. Most important to these firms' growth is an 'effective business model design, where decisions about core activities and where to focus investments are interconnected to decisions about location of activities, and about inward and outward relationships with other players' (p. 363).

Most scholars recognise that firms are continuously subjected to external environmental pressures and need to adapt their business models to preserve their relevance (Cavalcante, Kesting and Ulhøi, 2011; Wirtz, Schilke and Ullrich, 2010). In this context, Chesbrough (2010) finds, based on continuous experimentation, that BMA is crucial for new ventures. This experimental 
process leverages firms' dynamic capabilities and enables them to develop novel value offerings, implement new value chain structures and reconfigure their revenue models (Chesbrough, 2010). A new venture seeks a scalable, repeatable, profitable business model (Blank and Dorf, 2012). Therefore, the ability to dynamically adjust the business model to changing environmental conditions and emerging market opportunities is a key capability expected to increase a start-up's likelihood of survival in the short term and to support its growth in the medium and long term.

Based on this literature, this study addresses the relationship between BMA and the success of new firms. Responding to an empirical gap in the literature, we aim to understand whether the dynamic adaptation of the business model acts a clear, unambiguous driver of the success of the new venture. To do so, we proceed from the assumption that BMA is reflected positively in the survival, growth and profitability of the new venture. New ventures that dynamically adapt and re-configure their business model to ensure alignment and coherence with the competitive landscape and market opportunities and feedback should have higher chances to succeed. Therefore, we test the following research hypothesis:

BMA is positively connected with the success-survival, growth and profitability - of the new venture.

\section{MetHOdOLOGY}

This paper is based on a multiple case study design (Yin, 2009). Given the lack of rigorous, theoretically guided and empirically based approaches in research on BMA (Zott, Amit and Massa, 2011), we adopt an inductive methodology to analyse and compare a selected number of innovative new ventures. Such research is especially useful as it allows making comparison between BMA processes and, thus, is likely to enable the development of theory about BMA and its relationship to the success of new ventures (Eisenhardt and Martin, 2000; Yin, 2009).

\section{Selection of case studies}

Preliminary unstructured interviews with external experts were conducted to select relevant case studies. We interviewed the managing directors of three business incubators and the investment director of a venture capital fund. Their knowledge about the local start-up scene helped us pre-select five companies with common features: (1) survived the death valley; (2) showed growth over time; and (3) underwent several significant BMA processes. We did not look specifically for gazelle firms as we were not interested in understanding how outliers behave. We specifically asked about 
firms that could be considered representative of a normal, successful startup firm, leaving it to our interlocutor to define such a term. All the firms were approached in the fall 2014. Three accepted being interviewed, one declined for confidentiality reasons, and one postponed the interview. The three start-ups selected were founded in the 2008-2010 period, belong to different sectors and include external investors in their equity capital. Table 1 provides detailed information about the companies.

Table 1. Case studies: selected data

\begin{tabular}{|c|c|c|c|}
\hline & MilkyWay & ModeFinance & O3 Enterprise \\
\hline Year of establishment & 2011 & 2010 & 2008 \\
\hline Location & $\begin{array}{l}\text { Knowbel Start-ups } \\
\text { Incubator, Modena, } \\
\text { Italy }\end{array}$ & $\begin{array}{l}\text { Area Science Park, } \\
\text { Trieste, Italy }\end{array}$ & $\begin{array}{l}\text { Area Science Park, } \\
\text { Trieste, Italy }\end{array}$ \\
\hline Sales (Euro) (2013) & 125,000 & 294,000 & 479,000 \\
\hline Employees (2013) & 7 & 5 & 6 \\
\hline $\begin{array}{l}\text { Total Investments } \\
\text { (Euro) (2013) }\end{array}$ & 345,000 & 406,000 & 446,000 \\
\hline External Investors & $\begin{array}{l}\text { TT Venture (venture } \\
\text { capital fund) } \\
\text { Atlante Seed ( venture } \\
\text { capital fund) }\end{array}$ & $\begin{array}{l}\text { Friulia S.p.A. (venture } \\
\text { capital fund) } \\
\text { C.G.N. Servizi } \\
\text { (customer/reseller) }\end{array}$ & $\begin{array}{l}\text { Insiel Mercato S.P.A. } \\
\text { (customer/reseller) }\end{array}$ \\
\hline
\end{tabular}

Source: Aida Database by Bureau Van Dijk.

\section{Data collection}

Data on these new ventures were collected through three main sources: (1) direct, semi-structured interviews with the founders/entrepreneurs; (2) informal follow-ups through e-mails and virtual meetings; and (3) collection of secondary data, including both public (e.g. public annual reports, articles in business newspapers and blogs) and internal materials. Data sources were triangulated to mitigate the risk of informant bias (Gibbert et al., 2008).

At least two interviews were conducted with each company to describe the firms' current and initial business model configurations and the drivers that led to BMA. All interviews took place between July and October 2014, and each lasted 60-120 minutes. The interviews were taped, transcribed literally and reviewed by the interviewees to improve accuracy (Huber and Power, 1985).

The interviews were based on the framework provided by Morris, Schindehutte and Allen (2005), in which a business model refers to a set of six fundamental components: 1 ) value offering; 2 ) market segments; 3 ) core 
competences; 4) competitive strategy (external positioning, in the original formulation of Huber and Power, 1985); 5) cost and revenue model; and 6) entrepreneurs' motivations. The value offering is related to the nature of the product or service mix and the process of value transfer to the client. Market segments refer to the nature and scope of the market to which the firm's offerings are addressed. Core competences are the internal resources and capabilities which should enable a firm to perform better than its competitors. Competitive strategy refers to how the firm achieves advantages over its competitors by relying on these core competencies. The cost and revenue model reflects the economic logic of expenses, earnings and profits. Finally, entrepreneurs' motivations describe the entrepreneurs' ambitions regarding time, size, and business scope.

Informants were asked first about the actual configuration of these six components of their business model. The actual business model configuration was used as a starting point to retrieve, through a retrospective approach, the changes which occurred in the business model from the foundation of the firm and the reasons behind these changes. The laddering technique was used to capture entrepreneurial motives and goals connected to the business model reconfiguration.

\section{Data analysis}

First, interviews were coded and analysed by two independent researchers, focusing on the six fundamental components of business model architecture (Strauss and Corbin, 2008). Next, the coded materials were combined and refined if any deviations occurred. Second, a within-case analysis was developed for each case based on the six fundamental components of business model architecture. This within-case analysis permitted clarifying the drivers that led to BMA (Yin, 2009). Third, to identify a series of common BMA patterns, a cross-case analysis was developed (Eisenhardt and Graebner, 2007). Iterating between theory and multiple case analysis clarified the theoretical argumentation (Eisenhardt, 1989).

\section{RESULTS}

This section presents the insights derived from the analysis of each case, the within-analysis and cross-case analysis in relation to the literature on BMA.

\section{MilkyWay}

MilkyWay is a new Italian venture which focuses on the design, manufacture and online sale of trial bikes and action-sport equipment (Table 2). The firm was 
established in 2010 by a mechanical engineer (Jacopo Vigna) with experience in the biomedical field and the racing departments of two leading motorbike manufacturers. The start-up enjoys the capital provided by an angel investor and the support of a technology-transfer centre at the University of Modena. In 2012, Vigna was selected to participate in the SeedLab acceleration program, which enabled better identifying and improving MilkyWay's actual business model. In 2013, two venture capital funds invested a total of EUR 720,000 in the company's equity.

MilkyWay's initial business idea was to transfer technological innovations from the motorsports industry to the trial bike sector. Bikes and bike parts and components had been addressed to a specific tribe (trial bikers) and sold through an e-shop. To create a community-based marketplace and expand long-tail demand, MilkyWay became a reseller of products and devices connected to action sports (e.g. skating, surfing, kite-surfing, parkour) and started to invest in the development of a proprietary platform (community + e-commerce) in 2012. As of 2014, the overall assortment had 31 categories and more than 16,000 references. The proportion of MilkyWay's total sales accounted for by assembled product has diminished. The initial target market was trial-bikers, but this global niche is too narrow to support a real growth. MilkyWay has progressively broadened its target market into action sports lovers/addicts. The basic idea is to exploit long-tail demand composed of many sub-segment and cross-selling opportunities (extreme athletes usually practice different disciplines). Today, trial bikes still contribute $50 \%$ of total sales.

The company initially opted to offer unique high-tech products (assembled bikes and special components) at premium prices but recently aligned the price positioning of resold items with its competitors (e-shops). MilkyWay first focused on its technological competences and founder's networking capabilities. The investment of venture capital funds significantly changed the internal organisational structure (some roles are internalised, and the firm has 10 employees), creating the possibility to focus on development of the internal platform (e-commerce + e-community). E-commerce serves as the firm's main (and unique) source of revenue. Its customer base has expanded significantly during the past two years. Customer loyalty and sales per customer remain low because of difficulties in platform implementation. Initially driven by the search for excellence and the desire to create superior products and components, the firm's growth orientation is reflected in the search for a scalable business model and the development of a user-oriented platform (e-shop + community). 


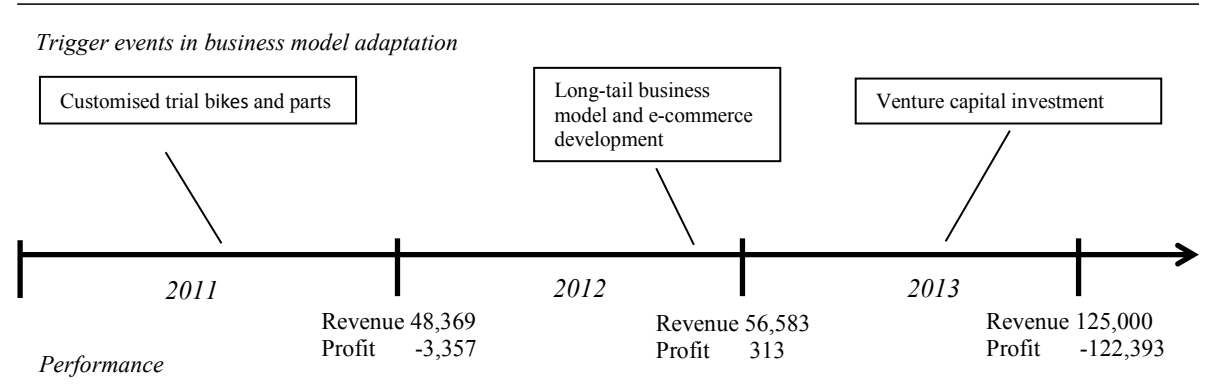

Figure 1. MilkyWay business model adaptation and performance (Euro)

\section{ModeFinance}

ModeFinance is an Italian venture in the financial consulting sector. Operating as a university research project since 2003 , the company was established in 2009 and is in the business incubator of Area Science Park in Trieste (Table 3 ). The business is based around proprietary technology for credit risk analysis. The firm provides clients (mostly importantly, firms, banks and insurance companies) with various reports evaluating the overall economic sustainability and creditworthiness of firms.

Initially, the company produced credit reports for a unique client that was also its unique supplier. This client remains a multinational company offering credit rating and business intelligence services and databases. ModeFinance uses the data provided by this multinational to generate credit rating reports which the multinational firm resells to its clients. This activity remains part of ModeFinance business and accounts for some $30 \%$ of its actual turnover.

ModeFinance soon decided to develop a market for its proprietary products, simple software targeted at banks and bigger firms to help them analyse the creditworthiness of their clients. The proportion of the company's total revenues from this activity remains marginal. Since 2010, the company has sold credit reports directly to big firms. The majority of ModeFinance's revenues comes from this activity, which has been highly standardised. The firm also produces more comprehensive reports, combining qualitative (strategic, organisational) and quantitative (financial) data and information on single firms, especially in preparation for merger and acquisition processes. Such reports require a significant amount of human intervention. In 2012, the company launched an App for mobile devices (S-peek) that allows users to obtain standardised credit reports. The product is intended to increase the business's scalability but, so far, generates only a marginal portion of the company's total revenues. 
Excluding the multinational company that initially supported the new venture and remains its most important client, ModeFinance does not target a unique market. Clients vary from medium-sized to big firms, from financial intermediaries to business consultants. The company directly serves approximately 100 customers and another 300 through the intermediary of the partner multinational. The S-peek app has been downloaded by thousands of users worldwide. No information exists on these users.

To compete in a sector dominated by big players, ModeFinance has adopted a cost-leadership strategy. Its prices are, on average, 30\% lower than competitors. To sustain this price positioning, the company has been forced to gradually standardise its offerings. This strategy has not changed over time.

So far, the company has been growing mostly due to its technological (the development and refinement of its rating algorithm) and supply chain (scouting and management of data and information suppliers in foreign markets) capabilities. Its weak sales and marketing capabilities are its Achilles's heel and main constraint on growth.

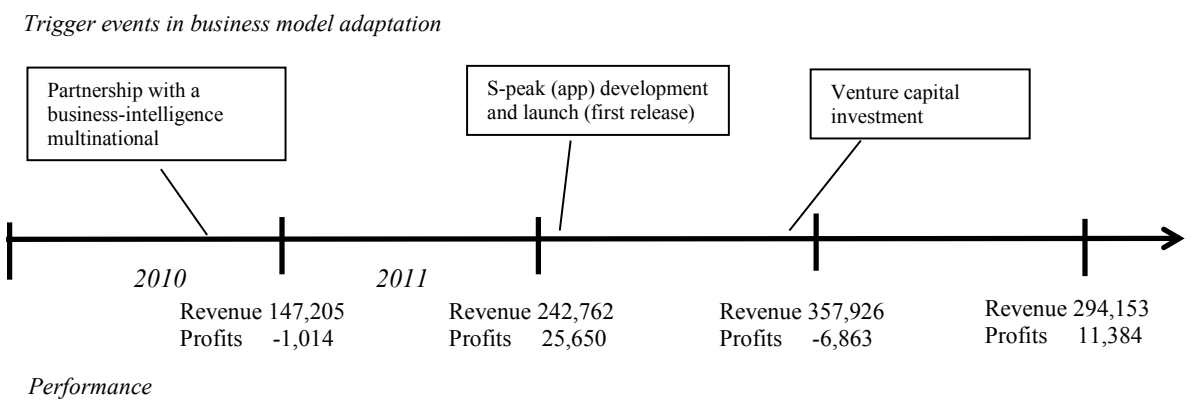

Figure 2. ModeFinance business model adaptation and performance (Euro)

ModeFinance's revenue streams are quite diversified. It obtains license fees from its historical partner, receives cash from direct clients and collects revenues from its app users (cut by the percentage due to the platform's owners). Occasionally, the firm also looks for extra revenues from statefunded research projects. In 2013, these revenues provided approximately $25 \%$ of the firm's total turnover.

The firm directly manages all its core activities. It limits outsourcing to specific non-core, business-related services, such as accounting. The entrepreneurs have been systematically oriented to the growth of the business since its founding. 


\section{O3 Enterprise}

O3 Enterprise is an Italian company offering digital imaging services in the medical sector (Table 4). It provides solutions for the visualisation and management of patients' clinical data. The idea originated from an academic research project in 2004, and the company was established in January 2008.

The company started as a provider of open-source solutions for the visualisation of clinical data (especially images) of patients. The importance of the product in the company's offerings was prominent. Recently, the company completely revised its strategy to offer a cloud-based solution for archiving, visualising and reporting clinical data (images, videos and signals). The importance of the main product has diminished, while the importance of and the revenues from complementary services, such as project design, installation and maintenance, have increased.

Starting with a partially incorrect definition of its target market (too broad and partly inaccessible because of regulatory constraints), 03 Enterprise has progressively focused on the medium-sized, private hospitals market. It has started, in parallel, a process of progressive internationalisation. To quickly obtain market share, the company initially opted for penetration prices (up to $50 \%-60 \%$ below its competitors). The prices, especially for ancillary

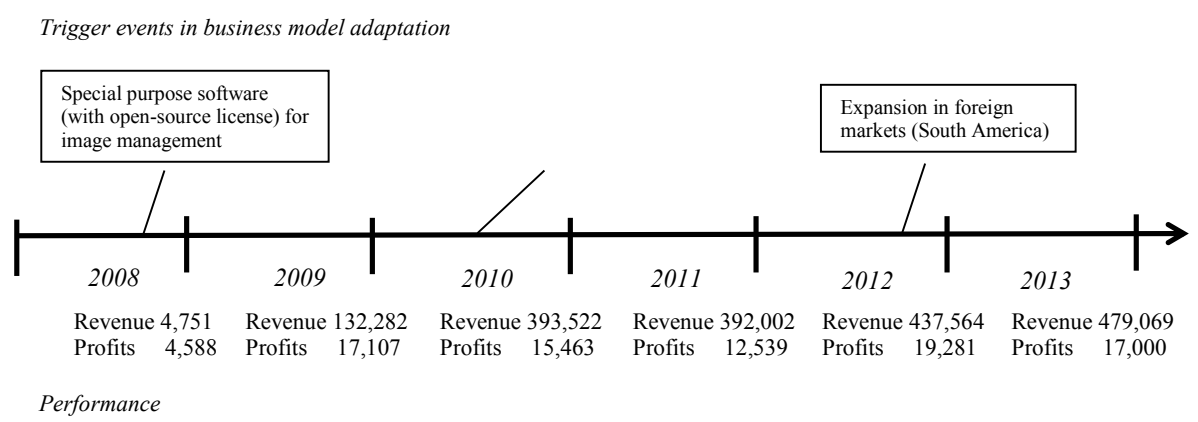

Figure 3. 03 business model adaptation and performance (Euro)

As the chief executive officer states, 'the first years were the ones of technological exploration. Now have come the years of market exploitation'. Indeed, the company grew around its technological capabilities in the first years. Its turning point can be identified as 2013, when 03 Enterprise decided to push on the sales accelerator, hiring a sales manager who raises revenues from foreign markets. 
Despite not significantly expanding its client portfolio during the 2008-2013 period, the company could increase its revenues by achieving a higher penetration with each client. Today, most revenues come from a few big clients. The company has been oriented to the systematic growth of its business since market entry. This orientation has never changed.

\section{Discussion}

The three cases examined in the previous section provide a quite rich array of BMA processes. Looking at common patterns among the three, five typical paths of BMA can be identified. First is the standardisation and modularisation of products and services, particularly serial solutions, for transaction efficiency gains (Amitt and Zott, 2001; Brusoni and Prencipe, 2001). MilkyWay shifted its offerings from customised trial bikes and parts and components to standardised products and action sports equipment (skating, surfing, kite-surfing, parkour) to seize the opportunities in a wider market. Sensing the opportunity to simplify its products and to commoditise mass-market access to financial information, ModeFinance developed an app for mobile devices (S-peek) and expressed the intention to further enlarge its assortment of standardised products through a partial reconfiguration of its internal capabilities. 03 Enterprise completely revised its offerings and coherently reconfigured its capabilities to move to a cloud-based solution for archiving, visualising and reporting clinical data (images, videos and signals).

For all the firms, the standardisation and modularisation process is difficult. Indeed, MilkyWay faces several technical problems in developing its e-shop and converting community members into effective customers. The first release of the app launched by ModeFinance was improved several times to accelerate its adoption by final customers. 03 Enterprise's standardisation of software required a substantial change in its relational approach to its main customers. These implementation problems affect the performance achieved by the three firms: positive revenue growth is associated with limited profitability.

A second common pattern is related to the creation of solutions. The three cases suggest that these three innovative ventures exploit the potential for value creation by offering customers bundles of complementary products and services (Amit and Zott, 2001). These bundling solutions sometimes rely on both vertical complementarities (products and services characterised by high vertical integration in the value chain) and horizontal complementarities (different solutions connected by cross-selling opportunities). After sensing a clear opportunity in the market, MilkyWay developed a wide assortment of solutions to exploit horizontal cross-selling opportunities in the action sports 
segment, where extreme athletes usually practice different disciplines. ModeFinance broadened its product assortment to explore new segments (small and medium enterprises) and better fulfil the horizontal needs of its main customers (banks). 03 Enterprise quickly revised its product strategy and offers a cloud-based integrated solution for archiving, visualising and reporting clinical data which is connected to other complementary vertical services, such as project design, installation and after-sales. The three firms implemented these moves in an agile way. In this sense, the firms' dynamic capabilities have been critical in keeping them alive and kicking in three highly dynamic business environments. However, the limited profits earned by the firms reveal that the exploitation of cross-selling opportunities through solutions building needs a long-term approach.

A third pattern is the fine-tuning of target markets. The observed firms do so continuously, with the aim to meet the needs expressed by different customer segments (Demil and Lecoq, 2010). Firms also focus on international markets, customers and niches and multiple distribution channels. For instance, MilkyWay has enlarged its target market from trial-bikers to actionsports lovers to exploit long-tail demand composed of many sub-segments. O3 Enterprise has progressively shifted its focus to the broader target market of medium-sized private hospitals. Simultaneously, it has started a process of progressive internationalisation through the establishment of a new channel of foreign distributors. ModeFinance has worked hard to escape the deadly hug of a single customer and uses three channels to distribute its services. The fine-tuning of these segmentation strategies has a direct effect on revenue growth but limited effect on profitability. These three new ventures expand and penetrate new markets at the expense of their overall margins.

The fourth pattern is the development of market-oriented competences. Three firms supplement their initial focus on technological know-how and product development capabilities with a strong effort directed to develop sales and marketing competences to support their competitive strategies and sustain their growth (Colombo and Grilli, 2005). MilkyWay invests in the implementation of an integrated platform (e-commerce and e-community) focusing on the enhancement of the user experience. After growing mostly through technological and supply chain capabilities, ModeFinance directs its attention to sales and marketing competences. 03 Enterprise attempts to move from technological exploration to market exploitation and has hired a sales manager to boost revenue from foreign markets. The reconfiguration of the companies' (marketing) capabilities is neither simple nor automatic. Their size liability hinders them from effectively developing new marketing competences. Closing the gap between the increasing complexity of markets and firms' limited internal ability to sense and seize new opportunities 
requires time. Consequently, the benefits for growth and profitability from reconfiguring companies' assets and competences remain quite limited in all the cases examined.

Finally, we see the fifth pattern of attracting external investors. The firms' commitment to growth attracts external investors (Davila, Foster and Gupta, 2003). In particular, MilkyWay acquired a business angel's investment and participated in a first-round of investment with two venture capital funds. ModeFinance's orientation to systematic business growth has attracted external investors (including a regional investment fund and a private firm). 03 Enterprise's strong entrepreneurial growth efforts have attracted an external industrial investor (a major customer who invested in the firm). So far, the results show that venture capital investment in the early stage of a firm does not imply the direct increase of the revenue growth rate and profitability. Venture capital allows new ventures to focus on the achievement of longterm performance, rather than short-term results.

\section{CONCLUSION}

The three start-ups examined are all involved in significant BMA processes. We can claim that, since their establishment, they have sought to improve their business models to ensure a better match with market demand and technological advancements. More specific customer needs, market misalignments and the ability to sense new technological potential have been the major common drivers of the dynamics of these firms' BMA processes (Mezger, 2014). Our findings are contrary to the well-established idea that innovative start-ups' initial business model sets their market potential. The cases of MilkyWay, ModeFinance and $\mathrm{O} 3$ Enterprise reveal that the long, complex, risky BMA process is as important as innovation in determining at least the survival of a new firm, which is the first step towards success. This process is far from complete at all the examined new ventures as they are still involved in the complex process of reconfiguring their key capabilities, including sales and marketing capabilities (Teece, 2010; Zahra, 2008).

Despite some difficulties in fine-tuning their ideas with their target markets in the first years since establishment, these firms can continuously spot new opportunities, effectively manage external risks and significantly evolve their internal resource base. Are these efforts enough to achieve growth and profitability? They are in part but not completely. Indeed, the main contribution of this study is to show that, in all the cases analysed, BMA is critical to guaranteeing firm survival in especially tough environments. However, we cannot claim that the results fully support the hypothesis that BMA is key to determining the growth and success of start-ups. The other 
perspectives presented in the literature review complement our findings and help better understand what drives (or partly drives) the growth of these firms. In particular, we find that internal capabilities (especially sales and marketing capabilities) and external connections play key roles.

This study, of course, has many limitations, of which the limited amount of companies studied is the most significant. Although qualitative, this study could have obtained a richer picture through the analysis of additional cases. The selection procedure used to identify the three cases involved (using experts in the field) could lead to biased selection. Despite a lack of spectacular results, the three firms analysed perform well in the market and might not represent the average start-up which struggles to survive and to grow. Future studies should address this topic using a quantitative approach, accounting for all the limitations related to the operationalisation of such a complex concept as that of the business model.

\section{References}

Almus, M., Nerlinger, E.A. (1999). Growth of new technology-based firms: Which factors matter? Small Business Economics, 13(2), 141-154.

Amit, R., Zott, C. (2001). Value creation in e-business. Strategic Management Journal, 22(6-7), 493-520.

Amoros, J.E., Bosma, N., Kelley, D. (2014). Global Entrepreneurship Monitor: 2013 Executive Report. London, GB: London Business School, and Wellesley, MA: Babson College.

Audretsch, D.B. (1995). Innovation and industry evolution. Cambridge, MA: MIT Press.

Audretsch, D.B., Feldman, M.P. (1996). R\&D spillovers and the geography of innovation and production. American Economic Review, 86(3), 630-640.

Baron, J.N., Hannan, M.T. (2002). Blueprints for success in high-tech start-ups. California Management Review, 44(3), 8-36.

Baron, J. N., Hannan, M.T., Burton, M.D. (1999). Building the iron cage: Determinants of managerial intensity in the early years of organizations. American Sociological Review, 64(4), 527-547.

Baum, J., Locke, E., Smith, K. G. (2001). A multidimensional model of venture growth. Academy of Management Journal, 44(2), 292-303.

Becattini, G. (1990). The Marshallian industrial district as a socio-economic notion. In F. Pyke (Ed.), Industrial districts and inter-firm cooperation in Italy (pp. 37-51). Geneva: International Institute for Labor Studies.

Beckman, C.M., Burton, M.D. (2008). Founding the future: Path dependence in the evolution of top management teams from founding to IPO. Organization Science, 19(1), 3-24.

Bhidé, A. (2000). The origin and evolution of new businesses. Oxford: Oxford University Press. 
Birley, S. (1985). The role of networks in the entrepreneurial process. Journal Business Venturing, 1(1), 107-117.

Blank, S. G., Dorf, B. (2012). The startup owner's manual: The step-by-step guide for building a great company. Pescadero, CA: K\&S Ranch.

Bloodgood, J.M., Sapienzan H.J., Almeida, J.G. (1996). The internationalization of new high-potential U.S. ventures: Antecedents and outcomes. Entrepreneurship Theory and Practice, 20(4), 61-76.

Braguinsky, S., Honjo, Y., Nagaoka S., Nakamura, K. (2010). Science-based business: Knowledge capital or entrepreneurial ability? Theory and evidence from a survey of biotechnology start-ups, IIR Working Paper Series, WP\#10-05. Institute of Innovation Research, Hitotsubashi University.

Brusoni S., Cefis E., Orsenigo L. (2006). Innovate or die. A critical review of the literature on innovation and performance, CESPRI Working Paper, 179.

Brusoni, S., Prencipe, A. (2001). Unpacking the black box of modularity: Technologies, products and organizations. Industrial and Corporate Change, 10(1), 179-205.

Carland, J. W., Hoy, F., Carland, J. A. (1988). Who is an entrepreneur? Is a question worth asking. American Journal of Small Business, 124(2), 3339.

Casadesus-Masanell, R., Ricart, J.E. (2010). From strategy to business models and onto tactics. Long Range Planning, 43(2), 195-215.

Cavalcante, S., Kesting, P., Ulhøi, J. (2011). Business model dynamics and innovation: Re-establishing the missing linkages. Management Decision 49(8), 1327-1342.

Chesbrough, H. (2010). Business model innovation: Opportunities and barriers. Long Range Planning, 43(2), 354-363.

Chesbrough, H., Rosenbloom, R.S. (2002). The role of the business model in capturing value from innovation: Evidence from Xerox Corporation's technology spin-off companies. Industrial and Corporate Change, 11(3), 529-555.

Chrisman, J., Bauerschmidt, A., Hofer, C.W. (1998). The determinants of new venture performance: An extended model. Entrepreneurship: Theory and Practice, 23(1), 5-30.

Colombo, M.G., Grilli, L. (2005). Founders' human capital and the growth of new technology-based firms: A competence-based view. Research Policy, 34(6), 795-816.

Davidsson, P. (1989a). Continued entrepreneurship and small firm growth. Stockholm: Stockholm School of Economics.

Davidsson, P. (1989b). Entrepreneurship-and after? A study of growth willingness in small firms. Journal of Business Venturing, 4(3), 211-226.

Davila, A., Foster, G., Gupta, M. (2003). Venture capital financing and the growth of startup firms. Journal of Business Venturing, 18(6), 689-708.

Delmar, F., Davidsson, P., Gartner, W. B. (2003). Arriving the high-growth firm. Journal of Business Venturing, 18(2), 189-216. 
Demil, B., Lecocq, X. (2010). Business model evolution: In search of dynamic consistency. Long Range Planning, 43(2), 227-246.

Djankov, S., McLiesh, C., Ramalho, R.M. (2006). Regulation and growth. Economic Letters, 92(3), 395-401.

Doloreux, D. (2003). Regional innovation systems in the periphery: The case of the Beauce in Québec Canada. International Journal of Innovation Management, 7(1), 67-94.

Duchesneau, D., Gartner, W. (1990). A profile of new venture success and failure in an emerging industry. Journal of Business Venturing, 5(5), 297312.

Eisenhardt, K.M. (1989). Building theory from case study research. Academy of Management Review, 14(4), 532-550.

Eisenhardt, K.M., Graebner, M.E. (2007). Theory building from cases: opportunities and challenges. Academy of Management Journal, 50(1), 25-32.

Eisenhardt, K.M., Martin, J.A. (2000) Dynamic capabilities: What are they? Strategic Management Journal, 21(10/11), 1105-1121.

Eisenhardt, K.M., Schoonhoven, C.B. (1990). Organizational growth: Linking founding team, strategy, environment, and growth among us semiconductor ventures 1978-1988. Administrative Science Quarterly, 35(3), 504-529.

Feeser, H.R., Willard, G.E. (1990). Founding strategy and performance: A comparison of high and low growth high-tech firms. Strategic Management Journal, 11(2), 87-98.

Fritsch, M. (1997). New firms and regional employment change. Small Business Economics, 9(5), 437-448.

Garnsey, E. (1998). A theory of the early growth of the firm. Industrial and corporate change, 7(3), 523-556.

Glaeser, E., Kallal, H., Scheinkman, J., Shleifer, A. (1992). Growth of cities. Journal of Political Economy, 100(6), 1126-1152.

Gibbert, M., Ruigrok, W., Wicki, B. (2008). What passes as a rigorous case study? Strategic Management Journal, 29(13), 1465-1474.

Gilbert, B.A., McDougall, P.P., Audretsch, D.B. (2006). New venture growth: A review and extension. Journal of Management, 32(6), 926-950.

Goffin, K., Mitchell R. (2005). Innovation management. London: Pearson.

Hansen, E.L. (1995). Entrepreneurial networks and new organizational growth. Entrepreneurship: Theory and Practice, 19(4), 7-19.

Heirman, A., Clarysse, B. (2004). How and why do research-based start-ups differ at founding? A resource-based configurational perspective. The Journal of Technology Transfer, 29(3-4), 247-268.

Huber, G. P., Power, D.J. (1985). Retrospective reports of strategiclevel managers: Guidelines for increasing their accuracy. Strategic Management Journal, 6(2), 171- 180.

Jaffe, A.B. (1989). Real effects of academic research. American Economic Review, 79(5), 957-970. 
Jaffe, A.B., Trajtenberg, M., Henderson, R. (1993). Geographic localization of knowledge spillovers as evidenced by patent citations. Quarterly Journal of Economics, 108(3), 577-598.

Kaplan, S.N., Sensoy, B.A., Stromberg, P. (2009). Should investors bet on the jockey or the horse? Evidence from the evolution of firms from early business plans to public companies. The Journal of Finance, 64(1), 75115.

Lee, C., Lee, K., Pennings, J.M. (2001). Internal capabilities, external networks and performance: A study on technology based ventures. Strategic Management Journal, 22(6/7), 615-640.

Marino, K.E., De Noble, A.F. (1997). Growth and early returns in technologybased manufacturing ventures. Journal of High Technology Management Research, 8(2), 225-242.

McDougall, P.P., Covin, J.G., Robinson, R.B., Herron, L. (1994). The effects of industry growth and strategic breadth on new venture performance and strategy content. Strategic Management Journal, 15(7), 537-554.

Mezger, F. (2014). Toward a capability-based conceptualization of business model innovation: Insights from an explorative study. R\&D Management, 44(5), 429-449.

Morris, M., Schindehutte, M., Allen, J. (2005). The entrepreneur's business model: Toward a unified perspective. Journal of Business Research, 58(6), 726-735.

Mullins, J.W. (1996). Early growth decision of entrepreneurs: The influence of competency and prior performance under changing market conditions. Journal of Business Venturing, 11(2), 89-105.

Onetti, A., Zucchella, A., Jones, M. V., McDougall-Covin, P.P. (2012). Internationalization, innovation and entrepreneurship: Business models for new technology-based firms. Journal of Management and Governance, 16(3), 337-368.

Pisano, G.P. (2006). Science business: The promise, the reality, and the future of biotech. Harvard: Harvard Business Press.

Pisano, G.P. (2010). The evolution of science-based business: Innovating how we innovate. Industrial and Corporate Change, 19(2), 465-482.

Porter, M.E. (1998). Clusters and the new economics of competition. Harvard Business Review, 76(6), 77-90.

Raz, O., Gloor, P.A. (2007). Size really matters: New insights for start-ups' survival. Management Science, 53(2), 169-177.

Sandberg, W. R., Hofer, C.W. (1988). Improving new venture performance: The role of strategy, industry structure, and the entrepreneur. Entrepreneurship: Theory and Practice, 2(1), 5-28.

Sapienza, H. J., Grimm, C.M. (1997). Founder characteristics, start-up process, and strategy/structure variables as predictors of short line railroad performance. Entrepreneurship Theory and Practice, 23(1), 5-24.

Siegel, R., Siegel, E., Macmillan, I.C. (1993). Characteristics distinguishing high-growth ventures. Journal of Business Venturing, 8(2), 169-180. 
Smallbone, D., Leigh, R., North, D. (1995). The characteristics and strategies of high growth SMEs. International Journal of Entrepreneurial Behaviour and Research, 1(3), 44-62

Stevenson, H.H., Jarillo, J. C. (1990). A paradigm pf entrepreneurship: Entrepreneurial management. Strategic Management Journal, 11(5), 17-27.

Stuart, R. W., Abetti, P.A. (1986). Field study of start-up ventures-part II: Predicting initial success. Frontiers of Entrepreneurship Research, 21-39.

Song, M., Podoynitsyna, K., Van Der Bij, H., Halman, J.I. (2008). Success factors in new ventures: A meta-analysis. Journal of Product Innovation Management, 25(1), 7-27.

Strauss, A.L., Corbin, J. (2008). Basics of qualitative research: Techniques and procedures for developing grounded theory. Thousand Oaks, CA: Sage.

Teece, D.J. (2007). Explicating dynamic capabilities: the nature and microfoundations of (sustainable) enterprise performance. Strategic Management Journal, 28(13), 1319-1350.

Teece, D.J., Pisano, G., Shuen, A. (1997). Dynamic capabilities and strategic management. Strategic Management Journal, 18(7), 509-533.

Terpstra, D. E., Olson, P.D. (1993). Entrepreneurial start-up and growth: A classification of problems. Entrepreneurship: Theory and Practice, 17(2), 5-20.

Thakor, M.V., Lavack, A.M. (2003). Effect of perceived brand origin associations on consumer perceptions of quality. Journal of Product and Brand Management, 12(6), 394-407.

Vivarelli, M., Audretsch, D.B. (1998). The link between the entry decision and post-entry performance: Evidence from Italy. Industrial and Corporate Change, 7(3), 485-500.

Watson, W., Steward W., Barnir, A. (2003). The effects of human capital, organizational demography, and inter-personal processes on venture partner perceptions of firm profit and growth. Journal of Business Venturing, 18(2), 145-164.

Wirtz, B., Schilke, O., Ullrich, S. (2010). Strategic development of business models: Implications of the Web 2.0 for creating value on the internet. Long Range Planning, 43(2), 272-290.

Yin, R. K. (2009). Case study research: Design and methods. Thousand Oaks, CA: Sage.

Zahra, S.A. (2008). The virtuous cycle of discovery and creation of entrepreneurial opportunities. Strategic Entrepreneurship Journal, 2(3), 243-257.

Zahra, S.A., Bogner, W.C. (2000). Technology strategy and software new ventures' performance: Exploring the moderating effect of the competitive environment. Journal of Business Venturing, 15(2), 135-173.

Zahra, S.A., Matherne, B.P., Carleton, J.M. (2003). Technological resource leveraging and the internationalization of new ventures. Journal of International Entrepreneurship, 1(2), 163-186. 
Zott, C., Amit, R. (2007, March-April). Business model design and the performance of entrepreneurial firms. Organization Science, 18(2), 181-199.

Zott, C., Amit, R. (2008). The fit between product market strategy and business model: Implications for firm performance. Strategic Management Journal, 29(1), 1-26.

Zott, C., Amit R., Massa, L. (2011). The business model: Recent developments and future research. Journal of Management, 37(4), 1019-1042.

Zucker, L., Darby, M., Brewer, M. (1998). Intellectual human capital and the birth of US biotechnology enterprises. American Economic Review, 88(1), 290-305.

\begin{abstract}
Abstrakt (in Polish)
W tym badaniu poszukujemy powiq̨zań między dostosowaniem modelu biznesowego i sukcesem nowych przedsięwzięć. W tym celu, przeprowadzamy dogłębnq analizę ewolucji modelu biznesowego trzech nowych włoskich przedsięwzięć w pierwszym roku ich działalności. Staramy się zrozumieć, czy i w jaki sposób ewolucja modeli biznesowych tych firm przekłada się na ich sukces. Nasza analiza pokazuje, że dostosowanie modeli biznesowych odegrało kluczowg rolę w umożliwieniu tym firmom przetrwanie $w$ ekstremalnie dynamicznych środowiskach. Jednak proces ten nie w pełni zadziałał jako katalizator procesów wzrostu i nie zwiększył rentowności firm.
\end{abstract}

Słowa kluczowe: dostosowanie modelu biznesowego, model biznesowy, nowe przedsięwzięcia, przeżycie, wzrost.

\title{
Biographical notes
}

Bernardo Balboni, Ph.D., is Research Fellow at the University of Trieste. His research interests include business marketing, international business, and SMEs' growth dynamics. On this topics he has published in several international journals, including Industrial Marketing Management, Marketing Intelligence and Planning, The Service Industries Journal, Transformations in Business \& Economics. He has also written some book chapters, and he presented several papers in different international conferences (RENT, EIBA, AIB, EMAC, EURAM). Guido Bortoluzzi, Ph.D., is Assistant Professor of Innovation Management at the Department of Economics, Management, Mathematics and Statistics "Bruno de Finetti" of the University of Trieste (Italy). He has been visiting lecturer in several international institutions worldwide, including University of Northern Colorado (Greeley, U.S.), Lingnan (University) College (Guangzhou, PRC) and ISM University of Economics and Business (Vilnius, LT). His research interests deal with SMEs, strategy and international business. He has published in several international journals, including Harvard Business Review (German edition), International Marketing Review, European Management Journal, European Business Review, Journal for International Business and Enterprise Development, Transformations in Business \& Economics. 